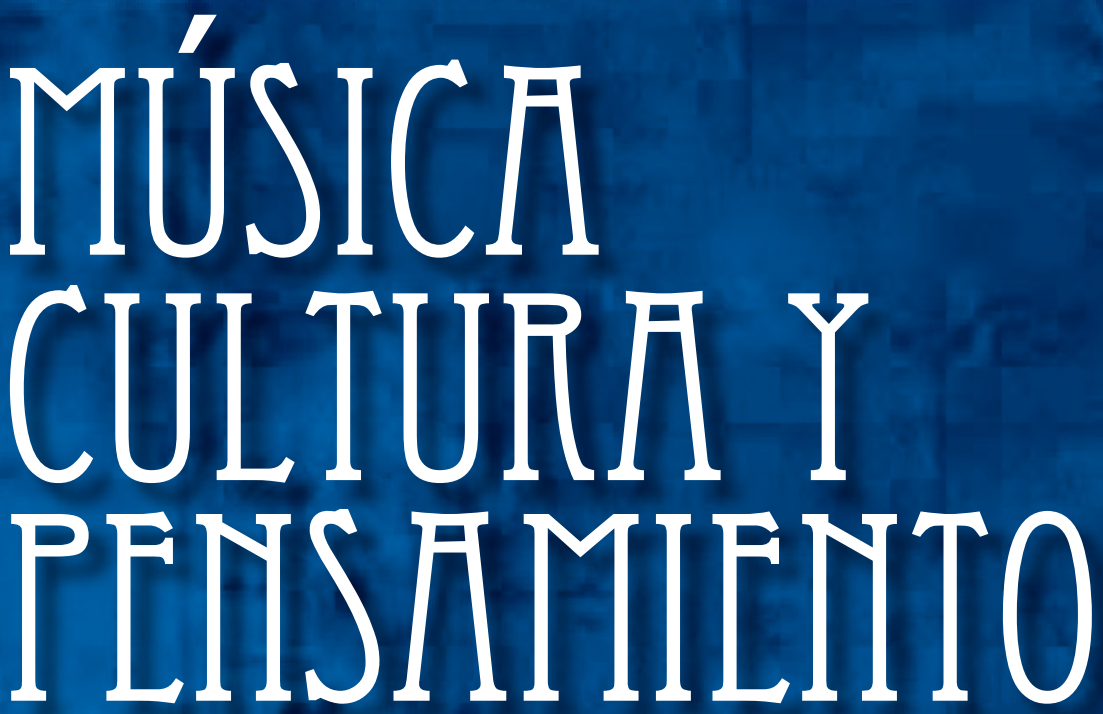

Revista de investigación de la Facultad de Educación y Artes del Conservatorio del Tolima

VOL. VIII N.o 8 - Noviembre 2019
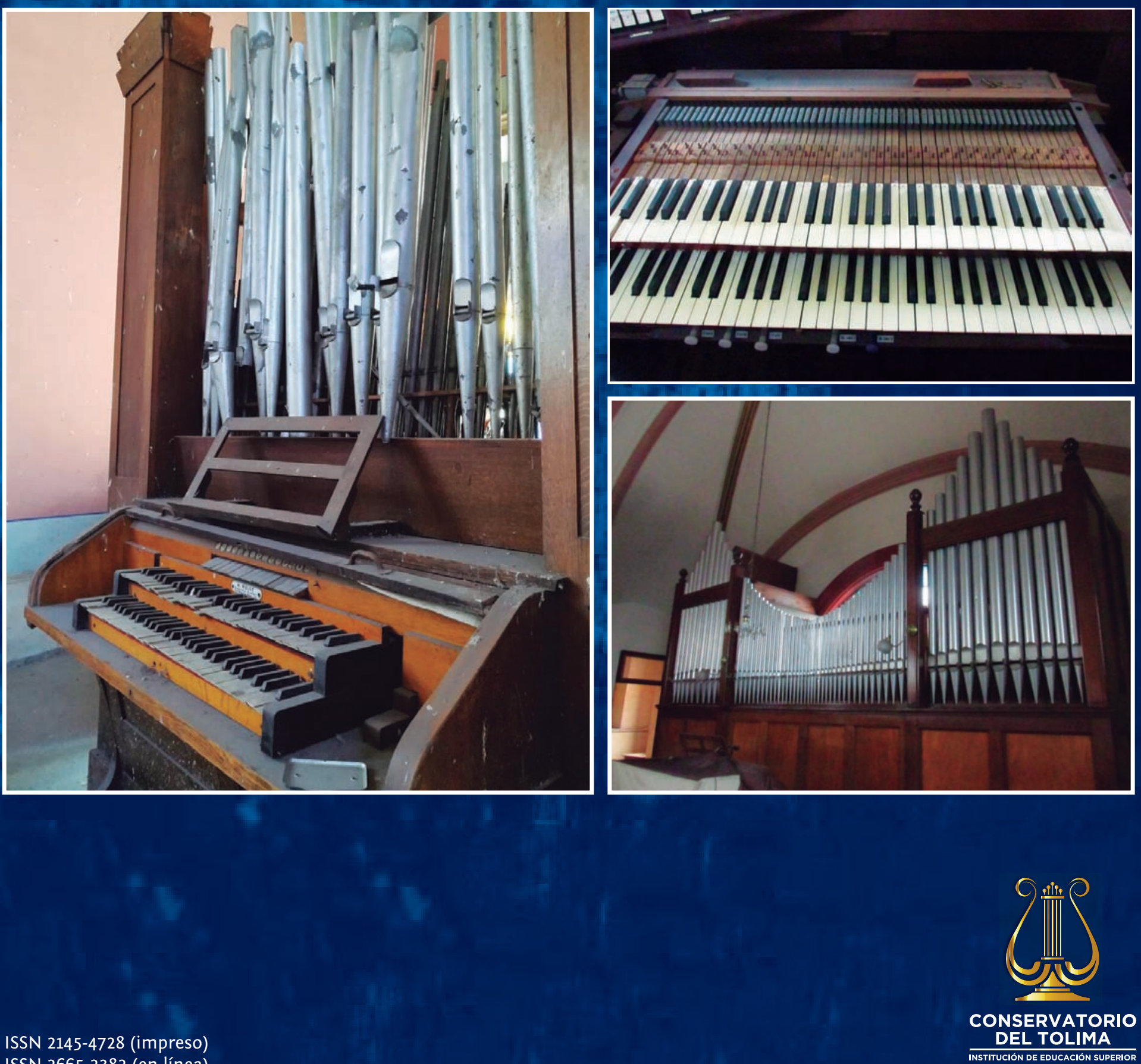


\section{La música en México: reflexiones sobre su historia particular}

Por: Alejandro Mercado Villalobos ${ }^{1}$

Artículo de reflexión

Recibido: 15 de junio de 2018

Aceptado: 15 de noviembre de 2019

Para citar este artículo/To reference this article: Mercado, A. (2019). La música en México: reflexiones sobre su historia particular. Música, Cultura y Pensamiento, 8(8), 5-24.
1 Doctor en Historia por el Instituto de Investigaciones Históricas, de la Universidad Michoacana de San Nicolás de Hidalgo, México. Profesor-investigador adscrito al Departamento de Estudios Culturales, de la División de Ciencias Sociales y Humanidades, Campus León, de la Universidad de Guanajuato. alejandro.mercado@ugto.mx
The music in Mexico: Notes about his particular history

\section{Resumen}

Este trabajo es una revisión histórica de la música en México. El interés principal es mirar las maneras en que se han construido los elementos de identidad, esto en función de su origen histórico y su impulso o imposición, ya sea por parte del Estado o por las élites de poder intelectuales, de las empresas comerciales o desde los ámbitos populares. Se trata de hacer específicos los momentos clave de arribo y adopción locales, de aquellos componentes artísticos que integran la música considerada mexicana. Se parte de la idea de que en México sobreviven identidades musicales múltiples, y de que, a lo largo de la historia nacional, por influjo de los movimientos políticos que posibilitaron las influencias culturales, se han venido incorporando elementos que han enriquecido la música considerada mexicana.

Palabras clave: música, fiesta, nación, nacionalismo, identidad.

\section{Abstract}

This article it's a history of music in Mexico. I analyses the music practice in some moments of his history. The principal interest is the discovery the elements of the cultural identity that arrived, specially, in XIX and XX centuries. The hypothesis it's simple: the Mexican music has been influenced of the exterior, the problem it's identify those musical influences and identify the process of the $\mathbf{5}$ acculturation, that produced the actual Mexican music. Keywords: music, party, nation, nationalism, identity. 


\section{Prolegómeno}

El México contemporáneo puede definirse como una república musical. En efecto, no Ehay espacio en el territorio donde no se haga y escuche música, reconociéndose, en todo caso, al menos dos universos sociales del arte.

Uno, tiene que ver con el reconocimiento de géneros en suma particulares, como la denominada música ranchera -título relacionado por el vínculo con la vida campirana(Peña, 1999, apud Díaz, 2015)² u otras formas, que, venidos de la canción popular, suelen tenerse como representativos de la nación entera. En este sentido, piezas musicales específicas se han consagrado como referentes de lo mexicano, y son requeridas en momentos particulares, donde es necesaria una evocación de lo propio, de lo que representa el ser nacional. Esto ocurre con Cielito lindo, por citar un caso, de Quirino Cortés y Mendoza (1859-1957). Se trata de una canción que se entona, comúnmente, en momentos donde es necesario dejar constancia del sentido de pertenencia a la nación mexicana, verbigracia, las justas deportivas. Lo mismo ocurre en ceremonias cívicas al interior del país, cuando se ejecuta el Himno nacional mexicano, que incide en el entendimiento de la población general que se identifica con el territorio al cual pertenece. Hay también otras piezas, que desde el ámbito de la música de concierto se han convertido en emblemas del nacionalismo musical mexicano, y que han sido inspiradas, de alguna manera, por la canción popular. Durante el siglo xIx hay ejemplos variados, como la Marcha Zaragoza, de Aniceto Ortega (1825-1875), o Ecos de México, de Julio Ituarte (18451905); para el siglo xx, una pieza muy significativa es el Huapango, del ínclito jalisciense José Pablo Moncayo (1912-1958).

En otro universo está lo local. México es un país pluriétnico y, en consecuencia, pluricultural. La diversidad cultural supera en mucho la división político-territorial, por lo que se tienen múltiples regiones culturales donde se ha desarrollado música variada, no solo por lo heterogéneo de los instrumentos utilizados -algunos de herencia prehispánica-, sino también por la multiplicidad de expresiones rítmicas y sonoras, con versos que implican una realidad particular, ya sea con relación a labores agrícolas y otras actividades productivas -como el trabajo en obrajes y fábricas-, la política y los movimientos sociales, o las relaciones amorosas.

En todo caso, la música en México ha sido enriquecida a partir de un proceso de aculturación (Colombres, 2009) ${ }^{3}$ de elementos foráneos, venidos a partir de la Conquista, y no solo de los europeos, sino también de otros contactos con grupos específicos producto de ese momento histórico; verbigracia, las culturas africanas, de donde provienen, sobre todo, no solo tradiciones que hoy son significativas para determinadas comunidades (Amós, 2000) ${ }^{4}$, sino también la adopción de instrumentos de percusión y de ritmos bailables.

2 Para algunos investigadores, la canción típica decimonónica tomó el nombre, hacia la década de 1920, como canción ranchera.

3 Para el sociólogo argentino Adolfo Colombres (2009), este proceso ocurre cuando una cultura invade y se impone a otra, y tiene cinco fases: contacto, pacificación, contacto permanente, integración y asimilación. Luego del proceso, la cultura que asimila incorpora - por la fuerza- elementos de la cultura dominante (pp. 234-239).

4 El historiador mexicano Amós descubrió que la representación cultural denominada torito de petate visible en el estado mexicano de Michoacán, que consiste en un baile sumamente alegre cuyo actor principal es un toro hecho de madera, recubierto con fibra tejida de tule (planta acuática que, una vez secada al sol, se manufactura en diversas maneras) y adornado con papel de múltiples colores, es en realidad una costumbre traída consigo por esclavos africanos, quienes fueron conducidos para el trabajo agrícola en el pueblo de Tarímbaro, ciudad aledaña a la capital de dicha entidad, en el siglo xvII. El asunto es que tal costumbre fue adoptada por los indígenas de la zona, quienes incluyeron elementos propios, resultando ello en una tradición ya no africana sino michoacana, y que es actualmente reconocida como patrimonio cultural de la entidad. 
Debe tenerse en cuenta, entonces, que lo que se tiene como propio en términos de música debe verse desde dos ámbitos de entendimiento. Uno, se relaciona con lo que se reconoce en lo general, lo que se acepta como inherente a la nación y, en consecuencia, a los individuos que a ella pertenecen, lo que se ha favorecido, he de comentar, desde el empuje de las élites políticas, pero sobre todo intelectuales. En otro orden está la música de las múltiples regiones musicales mexicanas, desarrollada desde el seno de las comunidades indígenas o mestizas, y que tienen una importancia mayúscula, no solo por generar un mosaico pluricultural musical extraordinario, sino también porque desde el ámbito regional se ha nutrido la música considerada mexicana, que no es otra que aquella que se tiene como representativa del país y que se reconoce así al interior y hacia afuera de México. Picún y Carredano (2012) hablan muy bien de esto en su trabajo El nacionalismo musical mexicano: una lectura desde los sonidos y los silencios ${ }^{5}$.

En todo caso, ¿cómo determinar la música que se sabe y acepta como mexicana? ¿Qué elementos culturales definen aquellos géneros considerados inherentes a lo mexicano en términos del arte musical? Más aún, en una nación pluricultural como México, ¿resulta viable definir una música que represente de manera general a la nación? Es posible tener un acercamiento a estas cuestiones a partir de una revisión histórica de la música en México. En efecto, los elementos del arte que hoy se reconocen como inmanentes a la nación, tanto música e instrumentos como grupos musicales específicos, se han adoptado como propios en el transcurso de una historia musical intensa. Es posible, entonces, acercarse a la comprensión de la música hecha en México, o mexicana, a partir de un estudio de la historia que dicho arte ha tenido en el país.

Para lo anterior, aunque se hará mención a los períodos prehispánicos (2600 a. C. - 1521 d. C.) y virreinal (1521-1821), me propongo el examen específico del período de gobierno de Porfirio Díaz, conocido en la historiografía al respecto como porfiriato (1876-1911). Aquella fue una época de amplio desarrollo artístico, posibilitado por un apoyo institucional extraordinario. Otro momento significativo es el impulso que en materia de desarrollo cultural ocurrió en México, a partir de la década de 1920. En esa y las siguientes se llevó a cabo un importante proyecto de (re)construcción nacional, en cuyo caso la música fue fundamental. Es la época de José Vasconcelos, en la dirección de un proyecto cultural nacional, y del nacionalismo musical mexicano cuyo empuje se ejemplifica con la importante labor de Carlos Chávez y Silvestre Revueltas. Finalmente, habré de hacer una mención especial de la "nueva" música mexicana, cuya (re)invención corrió a cargo de empresas televisivas -Televisa y TV Azteca-, con impulso importante en la década de 1990.

En suma, a partir de una exploración de la historia de la música en México, intento descubrir la forma en que, en momentos específicos, se ha construido una idea precisa de la música mexicana. Importa mirar las maneras en que se han percibido dichos elementos en función de su origen y su impulso, ya sea desde un proyecto de Estado, las élites del poder intelectuales, de las empresas comerciales o desde los ámbitos populares. Debo advertir que no se abordará en el trabajo las múltiples identidades regionales, dado que tal objeto de estudio supera el objetivo primario del presente trabajo. Más bien, se trata de hacer específicos los momentos clave de arribo y adopción locales, de aquellos componentes artísticos que integran la música considerada mexicana. He de comentar que tampoco se pretende establecer una definición de lo que es música mexicana al ser esto imposible en una nación que, como ya se señaló, es pluriétnica y multicultural. 
Al contrario, el estudio parte de la idea de que hay identidades musicales múltiples, y de que, a lo largo de la historia nacional, por influjo de los movimientos políticos que posibilitaron las influencias culturales, se han venido incorporando elementos que han enriquecido dichas identidades.

Cierto es que, como se verá durante el desarrollo del presente trabajo, en momentos específicos de la historia musical mexicana, los sectores de poder intentaron con cierto éxito imponer una determinada música: la europea durante el siglo xix, y la pretendida nacionalista en la primera mitad del siglo xx. Empero, la riqueza musical en México va más allá de un género o estilo musical, y sobreviven y con fuerza expresiones regionales que dan prueba de una diversidad extraordinaria, evidente, entre otras cosas, en la existencia y amplia difusión de festivales de música tradicional por todo el país; verbigracia, la Guelaguetza en Oaxaca, o el festival de Zacán, en el estado de Michoacán, por citar dos casos específicos. De todo esto, se resuelve entonces que la música en las regiones de México hace evidente la vigencia de identidades musicales múltiples, y que, aunque desde las instituciones culturales se intente definir lo que es propio, aun con denominaciones de patrimonio cultural, como ocurrió, por ejemplo, con el mariachi en el 2011 por parte de la Unesco, lo cierto es que la música mexicana existe solo en función de reconocer la existencia de los dos universos, mencionados al inicio: el que podría determinarse general, y que corresponde a aquello que se admite como propio, nacional, a impulso o imposición mediante el proceso de aculturación; y aquel que se desarrolla en las regiones, que es múltiple y diverso, y que aunque en parte se rige por la adopción del lenguaje musical e instrumentos importados, se asume como nacional en función de que se genera en comunidades indígenas o mestizas, y que se toman también como referentes de identidad nacional.

\section{La música en la historia de México}

\section{La época prehispánica}

La historia musical de México se remonta al período previo a la llegada de los conquistadores europeos (2600 a. C. a 1521 d. C.). Durante aquella etapa histórica se desarrollaron culturas -como la Olmeca, Maya, Mixteca-Zapoteca, Teotihuacana, Azteca, Purépecha, entre otras- de donde proviene una herencia que lleva implícita la aceptación de un pasado indígena, que hoy en día se asume como signo de identidad para la sociedad mexicana en su conjunto. Ahora bien, los religiosos que venían con los conquistadores españoles dejaron pruebas de la existencia de una amplia actividad artística en dichas comunidades prehispánicas. De tales testimonios y del estudio de imágenes musicales conservadas en códices y otros documentos similares (Marroquín, 2014) $)^{6}$ así como de los hallazgos arqueológicos con

6 Graciela Mirna Marroquín se tituló con un trabajo donde explora la música prehispánica a partir del análisis que hace, de imágenes dejadas por diversas culturas. Ella concluye, precisamente, que la música formaba parte fundamental de la vida cotidiana de los antiguos mexicanos, siendo los músicos un sector necesario. respecto a variados artefactos sonoros (Dájer, 1995), se deduce una práctica musical intensa, sobre todo en las ceremonias religiosas, que las había de forma cotidiana en los festejos que se organizaban en honor a las deidades indígenas (León, 2006) ${ }^{7}$, por lo que la música tuvo, en primera instancia, un carácter integrador en torno a la religión de los naturales.

En efecto, se hacía música en especial en las fiestas dedicadas a las múltiples deidades indígenas, con baile acompañado de cantos y sonidos de instrumentos de percusión y alientos, como tambores de diversa manufactura - verticales u horizontales- $y$ materiales también diversos, principalmente de madera, aunque los hubo también de barro. Algunos artefactos de percusión se confeccionaban de caparazón de tortuga (Civallero, 2015) $)^{8} \mathrm{u}$ otros animales, como conchas marinas o terrestres para hacer sonajas -hechas también de barro, o cascabeles; estos también se fabricaban de cobre en algunas culturas del

\footnotetext{
7 Hay diversas referencias al respecto. Cuando los españoles estaban ya en la ciudad de México-Tenochtitlán, en 1521, fueron testigos de la fiesta de Tóxcatl, en honor a Huitzilopochtli, donde los indígenas danzaban al son de cantos diversos.

8 Edgardo Civallero tiene un estudio interesante al respecto del uso de caparazones de tortuga en la música latinoamericana.
} 
Occidente de México. Los alientos fueron variados. Se tiene registro arqueológico desde la modificación intencional de caracoles marinos para generar determinada sonoridad, hasta silbatos o flautas elaborados en distintos tamaños y formas, ya fuese de barro, carrizo o madera, aunque fueron comunes también las que se manufacturaron de hueso animal o humano (Cfr., Schöndube, 1986); algunos instrumentos de aliento pudieron elaborarse de metal, posiblemente de cobre, como es el caso de Michoacán (Amós, 2018, pp. 13-15).

Estos antecedentes musicales son importantes, entre otras cosas, porque la tradición musical prehispánica sobrevivió la Conquista, y aunque desdeñada durante el siglo xIx, notas de aquella música e instrumentos mantuvieron vigencia hasta el día de hoy, formando parte de la identidad de regiones de México, especialmente en zonas indígenas reconocidas plenamente en el artículo $2^{\circ}$ de la Carta Magna mexicana (Constitución Política de los Estados Unidos Mexicanos, 2017).

El preclaro antropólogo mexicano Guillermo Bonfil Batalla (1989), en su libro México profundo. Una civilización negada, comprueba de alguna manera, la vigencia de los elementos actuales de herencia prehispánica. Bonfil concluye que, hoy en día, en todos los sentidos de la vida cotidiana mexicana es palpable el legado indígena: en el lenguaje, el modo de ser, en la forma de divertirse $y$, por supuesto, en las tradiciones, donde la música es elemental. $Y$ aunque con la conquista de México, los españoles pretendieron imponer a toda costa el modelo europeo, también en el ámbito cultural, los signos de las culturas precolombinas no solo sobrevivieron, sino que también forman parte fundamental de la realidad mexicana contemporánea.

\section{La música en la Nueva España}

Durante el período que inició en 1521 al caer militarmente la ciudad de México-Tenochtitlán, y que se extendió hasta 1821, al lograrse la independencia, arribaron múltiples elementos de la cultura europea, y ello dio pie a la asimilación cultural de diversos componentes musicales de Occidente, lo cual implicó un profundo desarrollo musical en el territorio actual de México, que fue nombrado por los conquistadores como "Nueva España”, en una época reconocida por la historiografía como virreinato o época colonial. Si bien es cierto que, en el afán por imponer el modelo político, económico y cultural europeo, los españoles desdeñaron lo local mpulsando, en el caso que nos ocupa, la música europea en todos los ámbitos de la vida colonial, es cierto también que en las comunidades rurales de pueblos y villas, y en los barrios pobres de las urbes novohispanas, se conservaron ritmos e instrumentos musicales prehispánicos, abonando a la construcción de una música propia, que, en uso de instrumentos europeos y con notación musical europea -a veces entremezclada con algún artefacto sonoro de antecedente prehispánico-, paulatinamente dio paso a la aparición de una música denominada por los propios españoles como sonecitos del pueblo o canciones del país, que, en lo sucesivo, daría cauce a la música asumida como mexicana, de lo cual hay evidencia palpable en la segunda mitad del siglo xVIII (Cfr., Moreno, 1979)9 . (León, 1974).

Se debe destacar que este proceso de aculturación enriqueció la cultura musical local y, en general, del territorio. En efecto, la adopción de la música europea, que se cultivó con formalidad dentro de los recintos religiosos, en lo que se conoce como capillas musicales ${ }^{10}$, favoreció el aprendizaje del solfeo, y la práctica de instrumentos que hoy son fundamentales en la música identificada como mexicana. El violín, la guitarra, el arpa, el contrabajo, y otros de cuerda y algunos también de alientos -flautas, oboes, clarinetes, entre otros-, arribaron a Nueva España en distintos momentos durante el virreinato (Vid., Mazín, 2006; Rodríguez-Erdmann, 2007), y no solo son fundamentales hoy en día en la música de concierto, sino que también dichos instrumentos forman parte elemental de los grupos tradicionales mexicanos, como el mariachi o diversos conjuntos como las orquestas purépechas en Michoacán, las bandas de viento que ejecutan en todo el territorio nacional, los grupos soneros de tierra caliente de Guerrero, o los conjuntos populares veracruzanos, por citar solo algunos ejemplos.

En suma, la música e instrumentos que arribaron de Europa en el período virreinal, no solo permitieron un desarrollo significativo de la música propia de los

9 El ministro del coro de la Catedral Metropolitana de la ciudad de México, de nombre José Paredes, informaba en 1796 que durante los actos litúrgicos los músicos de la capilla solían tocar piezas ciertamente populares. El organista, decía Paredes a un superior, tocaba “... seguidillas, tiranas, boleras y otras canciones gentilicias”. Años antes, en 1770, en el Teatro Coliseo de la ciudad de México se presentaban sonecitos como Los enanos o El perico, de la más pura extracción popular (Castellanos, 1969, apud Díaz, 2015, p. 63).

10 Hoy en día pueden consultarse variados estudios sobre las capillas musicales en México. Un trabajo reciente es el de Raúl Heliodoro Torres Medina (2016), titulado Música y catedral. Nuevos enfoques, viejas temáticas. 
sectores burgueses, sino además de toda una amplia expresión musical popular, por lo que paulatinamente y con evidencia documental durante la segunda mitad del siglo xvIII, solía escucharse en la Nueva España, en especial en barrios pobres de las ciudades o en el ámbito rural y campesino, canciones con ritmos que incitaban al baile y a la fiesta. Así, tocotines, chiqueadores, zarabandas, valonas, chaconas, jarabes, gatos, rumbas, habaneras, guarachas, entre otros, se escuchaban y bailaban en el territorio actual de México en la época española, interpretados por un músico lírico que solía ejecutar con vihuela o guitarra, también en pulquerías y cantinas (Ramos, 2010) ${ }^{11}$.

La música hecha durante el virreinato trascendió al siglo xix y más aún, se incorporaron nuevas formas musicales. En dicho período ocurrió la independencia de México -conseguida en 1821-, y todo un proceso nada simple que culminó en la consolidación del Estado durante el gobierno de Porfirio Díaz (18761911); esta fue una época de amplio desarrollo cultural, donde la música tuvo un papel fundamental en la construcción de la idea de nación.

En el México decimonónico arribaron formas musicales europeas modernas de acuerdo con el desarroIlo universal de la música de Occidente. Así, se ejecutaron sinfonías, óperas, fantasías, oberturas, marchas, mazurcas, vals, schottisch, polkas, entre otras. Además, ocurrió la conformación de grupos musicales específicos, entre estos las orquestas y diversos grupos de cuerdas, y las bandas de música de viento. Se desarrolló, entonces, un amplio espectro musical, que durante el siglo xix favoreció un gusto legítimo por la música de concierto, gusto que se extendió a los diversos sectores de la sociedad mexicana. En contraparte, ocurrió también una consecuente ampliación de los géneros populares, de aquella música producto del sincretismo que floreció en los barrios pobres de las ciudades y en el México rural, es decir, la mayoría de la población.

\section{La república musical mexicana}

\section{El contexto}

Formalmente, el 5 de febrero de 1824 se estableció el modelo republicano en México. En los años siguien-

11 En Nueva España había un amplio desarrollo de la fiesta en diversas manifestaciones, según ha descubierto Maya Ramos (2010), quien en su libro Los artistas de la feria y de la calle..., muestra los espectáculos que se organizaban sobre todo por sectores "marginales", donde la música era fundamental. tes - prácticamente hasta la segunda mitad del siglo xIX-, el país se debatió entre asonadas y motines que derivaron muchas veces en conflictos armados; esto fue producto de las disímiles posiciones políticas internas. Al respecto, el mayor debate ocurrió con el proyecto político impulsado por el grupo liberal encabezado por Benito Juárez, proyecto que tenía en sus bases la definitiva separación entre la Iglesia y el Estado y la radical transformación nacional a partir de los principios de libertad e igualdad, axiomas centrales del liberalismo Occidental, sustentados, a su vez, por la necesidad de instaurar regímenes democráticos.

Todo esto ocurrió en un contexto de presiones políticas y de invasiones extranjeras. Estados Unidos organizó una incursión militar a México en 1846 bajo el argumento de una deuda no pagada, siendo el saldo final la pérdida de una parte importante del territorio mexicano en el Norte. Luego, en 1862, invadieron los franceses, quienes impusieron el imperio del archiduque Maximiliano, que duró hasta 1867, año en que triunfó el grupo encabezado por el ínclito Benito Juárez García. Frente a los problemas por los que atravesó la nación, puede decirse que la primera mitad del siglo xix y parte de la segunda, el país fue un caos político, enmarcado en la guerra y las dificultades económicas producto de la misma.

\section{La música en la configuración de la identidad nacional}

Desde el inicio de la República, la música fue fundamental en la vida nacional. En uno de los estudios más recientes y que, a mi juicio, es uno de los más importantes en la historiografía contemporánea por su correcto planteamiento general y específico, sustentado además en una amplia documentación, se comprueba la forma en que la música acompañó el desarrollo del país durante el siglo xix (Vid., Miranda y Tello, 2013). Miranda cita como caso singular, la función de ópera que se llevó a cabo en la ciudad de México apenas conseguida la independencia, en honor a los miembros de la delegación inglesa, cuya visita significaba el reconocimiento de México como nación independiente por una potencia mundial. Para la ocasión se ejecutó a Rossini. El objetivo que buscaron las autoridades de la nueva nación -sostiene Miranda-, era mostrar al exterior el tipo de sociedad que pretendía constituirse, siendo la música una herramienta de construcción misma de la sociedad; la pretensión era seguir el ejemplo civilizado de algunos países de Europa. 
Para el filósofo mexicano Samuel Ramos (1968), esto equivalía al desdén de lo propio por considerarlo inferior, e imitar lo exterior -en este caso, la música europea-, al tenerla como un ejemplo venido de una cultura superior. En una opinión personal, considero que imitar la cultura de naciones como Francia, Alemania o Italia -de donde provino la ópera que se ejecutó en el México del siglo xIx-, tenía origen en el interés de las élites mexicanas por cimentar el país siguiendo ejemplos de naciones exitosas; la cultura era una manera para conseguir una nación moderna. Como sea, durante el siglo xix, la música europea tuvo un amplio desarrollo en el país, pues arribaron formas musicales en boga en Europa, música impresa e instrumentos, lo que favoreció la conformación de grupos musicales específicos, todo lo cual se consolidó ampliamente en el período conocido como porfiriato, entre 1876 y 1911.

El gobierno de Porfirio Díaz significó orden y progreso para México. Pese a ser un gobierno dictatorial por las continuas reelecciones y el uso del poder por un mismo grupo político por prácticamente tres décadas, aquella fue una época de consolidación política, económica, social y cultural.

El Estado mexicano se fortaleció generando un sistema central fuerte, que permitió un amplio período de paz y, a partir de ello, el impulso de programas en los diversos ramos de la administración pública. Con un gabinete de expertos, Porfirio Díaz apuntaló la economía del país: se sanearon las finanzas de la mano de José Ivés Limantour y se estimuló intensamente la inversión extranjera. Se implementaron planes importantes de educación nacional bajo la dirigencia de Justo Sierra, y se dio un amplio desarrollo al arte y la cultura, esto a partir del favorecimiento de proyectos educativos tanto en la capital del país como en las entidades. Durante el porfiriato, según veremos en seguida, se tomaron los elementos culturales de Europa, entre estos la música, y de esa aculturación surgió un México sumamente musical, donde se cultivó el arte propio hecho también por compositores mexicanos.

\section{¡Qué venga la música Don Porfirio!}

En el clásico estudio de Moisés González Navarro (1974), titulado El porfiriato. La vida social, que forma parte de la extraordinaria colección coordinada por Daniel Cosío Villegas, se percibe la manera en que se había tomado la música europea como modelo a seguir. González hace evidente la existencia de una sociedad festiva, que lo mismo organizaba un festejo por un santo patrono de algún pueblo o barrio urbano, que por una fecha importante del calendario cívico, y en cada oportunidad participaban prácticamente todos los sectores de la sociedad mexicana. La historiografía, al respecto -sobre todo la más reciente-, ha comprobado esta cuestión. Por mi parte, en el trabajo que realicé sobre música y músicos en la ciudad de Morelia, capital del estado de Michoacán (Mercado, 2009), pude corroborar el proceso de adopción de la música europea en la construcción de una idea de nación, y la manera en que cada proyecto educativo incluía la educación de dicha música y la formación de músicas ad hoc al modelo impuesto. El interés era no solo cubrir el tiempo de ocio de la población, sino también favorecer-mediante la fiesta- la construcción de lazos de sociabilidad entre los diversos sectores, fomentando con ello el carácter cultural del mexicano de aquella república musical.

Importa reafirmar que el proceso fue impulsado por las élites políticas, pero sobre todo intelectuales. En efecto, en un estudio que hice sobre Euterpe (Mercado, 2015a), una revista de "música y variedades" publicada en la ciudad de Morelia, en el estado de Michoacán, entre 1892 y 1894, se evidencia la intención cultural de los sectores dominantes: abogados, médicos, profesores, comerciantes ricos e incluso miembros de la Iglesia, por favorecer en todos los sentidos el aprendizaje y estudio de la música de concierto europea, y desde luego, su ejecución. En Euterpe escribía la intelectualidad moreliana, que se esforzó por difundir la cultura europea en el interés por construir una sociedad "civilizada", en función del ejemplo de naciones que en aquella época eran potencias mundiales. La música, en este aspecto, se concebía como una manera idónea para ello, en especial la ópera. En su trabajo titulado La República de la música..., Luis de Pablo Hammeken (2018) concluye precisamente, en que la ópera fue un elemento integrador de la sociedad mexicana, y una forma de alcanzar el grado de civilización parecido a los países ampliamente desarrollados en la época, verbigracia, Inglaterra, Estados Unidos, Francia, Alemania y otros. Y ello fue pensado a partir de la base ideológica que significó el positivismo, doctrina que fue la guía de los regímenes de gobierno en México durante la segunda mitad del siglo xix, especialmente durante el porfiriato (Ortega, 2010) ${ }^{12}$.

$12 \mathrm{El}$ impulsor del positivismo en México fue el médico y filósofo Gabino Barreda, quien fue discípulo de Augusto Comte en los estudios que realizó en Francia. Un estudio interesante, al respecto, es el de Aureliano Ortega (2010), titulado Gabino Barreda, el positivismo y la filosofía de la historia mexicana.
11

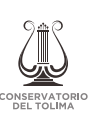


De lo anterior puede afirmarse que la música mexicana se nutrió de la imitación del arte musical europeo, importándose música e instrumentos musicales específicos, con los que se conformaron diversos conjuntos de cuerdas, entre estos las orquestas típicas que incluían también alientos, y bandas de música, que ejecutaron en espacios privados, pero sobre todo públicos, en una diversidad extraordinaria de festejos colectivos (Mercado, 2018a) ${ }^{13}$.

En la revisión de las fuentes ad hoc, en particular la prensa, que fue durante la época porfiriana un espacio idóneo para el fomento a la cultura $y$, por tanto, reflejo de la vida cotidiana (Pineda y Palacio, $2003)^{14}$, se descubre la manera en que arribaron las formas musicales europeas, y se convirtieron en el modo impuesto por los sectores dominantes. Del estudio de la prensa -sin olvidar otras fuentes-15, se deduce con claridad que durante el porfiriato se cultivó la ópera -al menos, se pusieron las arias de las obras representativas del género-, sobre todo las de Verdi y Rossini, dos de los compositores cuyas obras se ejecutaron comúnmente en el país. Se hizo mucha zarzuela en teatros formales en ciudades importantes, o en teatros improvisados en pueblos y comunidades rurales. También se escucharon fantasías; oberturas; marchas, un género importante en la construcción del nacionalismo mexicano; innumerables valses, que fue la forma musical preferida en los bailes porfirianos; variados schottisch; mazurcas; danzas; himnos, comunes en celebraciones cívicas; polcas y canciones, aunque también se incorporaron paulatinamente géneros modernos, de influencia norteamericana, como el two step, entre otros.

En suma, de la revisión hemerográfica con respecto a músicas, músicos y las músicas por ellos formadas, puede afirmarse la preeminencia de la cultura artística europea en la vida cotidiana del México decimonónico. Esto es evidente en cada programa musical organizado, ya fuese por una celebración religiosa -en el México decimonónico había un amplio calendario católico- o por algún festejo cívico, lo cual tiene relación con el adoctrinamiento en torno a los valores patrios, del ciudadano de la nueva República. Precisamente, alrededor de estos dos ejes: la fiesta

13A esta conclusión he llegado con mi más reciente trabajo, titulado Música y fiesta en Guanajuato (Mercado, 2018a).

14Sobre la prensa en México recomiendo la revisión del trabajo coordinado por Adriana Pineda Soto y Celia del Palacio Montiel (2003), titulado: La prensa decimonónica en México.

15 Aquí puede incluirse libros sobre la historia y la cultura mexicana publicados en el siglo xix, informes oficiales, memorias o diarios de personajes de la intelectualidad decimonónica, correspondencia, diarios de viajeros, entre otras fuentes de información. religiosa y la fiesta cívica, se generaron los elementos de identidad del mexicano que vivió en el siglo xIx. Y aunque había un México musical subyacente, el desarrollado en los sectores subalternos donde solía hacerse sones, huapangos, valonas y canciones con ritmos y letras de reflejo popular -urbano y rural, principalmente-, las élites favorecían en todos los ámbitos el desarrollo de la música europea.

Mucha de esta música de concierto - o clásica- se hizo por compositores mexicanos. En efecto, en diversas latitudes del país se escucharon piezas de los géneros musicales importados, pero con títulos y motivos musicales relacionados con la realidad social y cultural del México del siglo xix. En este aspecto, importa señalar que no pocos compositores tomaron temas centrales de canciones que se escuchaban en los espacios urbanos pobres o en los ámbitos rurales, para componer piezas que recogen ese mundo musical que hoy significa la identidad artística del país. Un ejemplo es Ecos de México, de Julio Ituarte (1845-1905), quien recogió en una obra magnífica con arreglo para piano, expresiones musicales de varias regiones del país. Ituarte compuso un popurrí con canciones populares difundidas en distintas épocas de la historia de México, y que hoy se tocan y forman parte de la tradición musical que es referente nacional.

Como con Ituarte, compositores mexicanos en distintos sitios de la geografía nacional, crearon obras donde puede notarse la identidad musical mexicana, ya sea en la melancolía inmersa en las piezas, en evocación a ese pasado lleno de conflictos donde la construcción nacional ocurrió en un proceso enmarcado en la Conquista, y luego, en continuas guerras internas o invasiones extranjeras, o en la alegría puesta en la música, en alusión a un pueblo festivo que a todo y por todo hacía fiesta. Apenas se están conociendo compositores mexicanos del siglo xIx, debido a la falta de estudios al respecto - uno de los pocos es el de Simón Tapia Colman (1991)-, y los que se conocen corresponden casi siempre a los que hicieron obra en las grandes ciudades, en especial en la ciudad de México. Más aún, de ellos a veces se conoce una o dos de sus obras y poco o nada se ejecutan hoy en día en las salas de concierto mexicanas (Adorno, 2000, citado por Brennan y Sarquiz, 2009) ${ }^{16}$.

\footnotetext{
16 En su interesante artículo de crítica a la situación de la música clásica en México, Juan Arturo Brennan y Óscar Sarquiz (2009) reflexionan acerca de lo poco que se ejecuta la música de compositores mexicanos, siendo predominantes en las salas de concierto mexicanas, los eminentes y famosos europeos de aquellas épocas que Theodor Adorno (2000) llamó “... la música de la plenitud de lo humano", esto es, de los siglos xviii y xix (p. 14).
} 
Como quiera que esto sea, del siglo xIx provienen varias de las piezas que son significativas de la música considerada mexicana. Baste citar la Marcha de Zacatecas, de Genaro Codina (1852-1901), que es de ejecución obligada en todo evento donde se requiera la evocación a lo propio, especialmente en las ceremonias cívicas: actos conmemorativos o desfiles. Otra pieza es el vals Sobre las olas, de Juventino Rosas (1868-1894), que es un emblema del nacionalismo que figura en el repertorio base de todo grupo musical, ya sea de orquesta o de banda de viento tradicional. Está también el propio Himno nacional mexicano, cuya música corresponde al español Jaime Nunó (1824-1908) y que, a partir de la imposición del Estado desde su estreno, ocurrido en septiembre de 1854 , genera sentimientos de pertenencia en los mexicanos. Los personajes citados, al igual que Cenobio Paniagua (1821-1882), Gustavo E. Campa (1863-1934), Melesio Morales (1839-1908), Ricardo Castro (1864-1907), Aniceto Ortega (18251875) -autor de la extraordinaria Marcha Zaragoza-, o Ernesto Elorduy (1854-1913), entre muchos más, figuran en la pléyade de compositores cuyas obras recogen esa identidad que hoy forma parte de esa música que se reconoce como de identidad nacional ${ }^{17}$.

\section{Educar en el arte}

Evidentemente, la música europea fue la que se enseñó en las escuelas, en particular en academias que funcionaron en colegios oficiales, en las escuelas normales, en seminarios eclesiásticos o incluso en espacios privados; por tanto, es lógico el hecho de que en cada festejo urbano o rural, fueron los géneros provenientes de Europa los que se ejecutaron en serenatas o audiciones, en funciones de teatro con óperas o zarzuelas, o hasta en funciones de cinematógrafo o en espectáculos circenses.

En varios espacios se enseñó la música en el siglo xix mexicano. En 1825, en la ciudad de México, se estableció el primer sitio dedicado a enseñar la música fuera del orden eclesial, en una iniciativa impulsada por el afamado músico vallisoletano José Mariano Elízaga ${ }^{18}$. Más tarde, también en la ciudad de México,

17 Recomiendo el interesante trabajo de Ricardo Miranda (2013), titulado Identidad y cultura musical en el siglo xix (pp. 15-79), incluido en la obra coordinada por él mismo y por Aurelio Tello.

18José Mariano Elízaga nació en 1786 en la ciudad de Valladolid (hoy Morelia). Desde niño mostró dotes extraordinarios en la música, que le valieron el mote del Mozart mexicano. Destacó como ejecutante de órgano y como profesor de música. Murió en 1842 (Vid., Romero, 1934). se crearían espacios de instrucción musical, a partir de los esfuerzos de Joaquín Beristáin y Joaquín Caballero en 1838 (Tapia, 1991), quienes crearían una asociación filarmónica desde donde se promovió la enseñanza musical; un año después haría lo mismo José Antonio Gómez (Romero, 1934). De estos esfuerzos surgiría, en 1866, el Conservatorio de Música de la Sociedad Filarmónica Mexicana, que a inicios del porfiriato tomaría el nombre de Conservatorio Nacional de Música de México, y que desde entonces fungiría como la institución de estudios profesionales de música más importante del país (Vid., Gómez, 2013).

Hubo, sin embargo, espacios de instrucción musical en distintas partes del territorio. Como ocurrió en la capital del país, en ciudades de provincia se organizaron asociaciones filarmónicas desde donde se favoreció la instrucción musical. Se tiene registro de varias de estas en Jalisco, Puebla, Campeche, Yucatán, Veracruz, Michoacán y Guanajuato, desde donde se impulsó la música Occidental (Cfr., Miranda, 2013) ${ }^{19}$. De igual forma, pero desde el Estado, se crearon espacios de educación musical al considerarse la música un elemento fundamental en la educación de la juventud mexicana, lo que correspondía al modelo educativo impulsado en la segunda mitad del siglo xIx, relacionado con la educación integral, que consistía en que debía ofrecerse al individuo todo aquel conocimiento que le formara en las distintas áreas del desarrollo; la música era uno de ellos (Bolaños, 2010). De esta manera, y atendiendo un estudio particular que realicé en tres escuelas de música porfirianas (Cfr., Mercado, 2015b), puedo confirmar que la música europea fue la que se enseñó en México durante el siglo xix en escuelas oficiales. Dicha música también se estudió en seminarios diocesanos, en conventos de religiosas y en academias particulares. Así, es posible afirmar que el mexicano decimonónico, sin importar su condición de clase, tuvo contacto permanente con la ópera y la zarzuela, siéndole familiar Verdi y Rossini, dos de los compositores más conocidos, aunque también escuchó otros compositores como Mozart, Beethoven, Liszt, Gounod, entre otros. Además, el ciudadano de la república musical mexicana pudo disfrutar de oberturas, fantasías, valses, polcas y canciones, en un panorama bastante amplio de festejo colectivo. De todo esto, evidentemente, derivó un gusto legítimo por la música de

19 He estudiado, en particular, las asociaciones filarmónicas que tuvieron parte en el proceso de enseñanza de la música en las ciudades de Morelia, en Michoacán, y León y Guanajuato en el estado del mismo nombre (Cfr., Mercado, 2009, 2018a). 
concierto europea, que hoy en día se mantiene de alguna manera, y que es cultivada por las músicas tradicionales en distintas regiones del país.

\section{Fiesta por todo motivo}

En el México decimonónico, como ya señalé, se hacía fiesta por motivos religiosos o en honor a la patria; el calendario en ambos casos es abundante. Por tanto, en torno a una conmemoración por el santo patrono de determinada ciudad o pueblo, o ante el pretexto, por ejemplo, del aniversario del inicio de la independencia -cada 16 de septiembre-, solía llevarse a cabo algún evento artístico con música vocal o instrumental, y esto se daba incluso en poblaciones medianas en provincia (Ochoa, 2015) ${ }^{20}$. El México festivo incluía audiciones por las tardes y serenatas en la noche; funciones en teatros -formales o improvisados-, de ópera y zarzuela, aunque también fueron comunes las funciones de cinematógrafo cuando el invento se generalizó en México, a finales del siglo xix (Vid., Leal, 2009). También, fue cotidiano que se organizaran desfiles, con carros alegóricos en ocasión de un festejo religioso, o militares cuando fuese la fiesta, motivada por una fecha del calendario patrio. Se organizaban cotidianamente carreras de caballos, corridas de toros, peleas de gallos, bailes, espectáculos con globos aerostáticos y funciones de circo. En todos estos casos hubo música. En espacios abiertos, en ocasión de un desfile o en audición o serenata, la banda de música fue el grupo protagonista; en cambio, en espacios cerrados, como teatros, espacios en edificios públicos o casonas de familias ricas en ocasión de alguna tertulia, fue la orquesta típica la que amenizó cada festejo social.

El caso es que la música significó la parte fundamental de la vida cotidiana en México, por lo que, a partir de esa cotidianeidad, durante el siglo xix se consolidaron piezas como referentes del nacionalismo, en géneros como las marchas y los himnos, aunque también valses y canciones se instalaron en el imaginario colectivo como referentes de lo propio. Ello fue posible gracias a la circulación de música impresa e instrumentos musicales, que favorecieron la conformación de conjuntos artísticos,

20 Álvaro Ochoa ofrece pruebas de esto en su estudio que realizó sobre el trompetista Rafael Méndez. El investigador recrea la vida musical del pueblo de Jiquilpan, Michoacán -que para 1910 contaba con 5000 habitantes (censo de 1910)-, donde es evidente la existencia de recitales con música vocal e instrumental, y toda una serie de eventos por motivos festivos diversos. especialmente grupos de cuerdas y alientos, y las bandas de música.

Al respecto, se sabe que durante la segunda mitad del siglo xix hubo en México un intenso comercio de insumos musicales. En el interesante libro Los papeles para Euterpe..., coordinado por Laura Suárez de la Torre (2014), se descubren datos importantes con relación a empresas que en México se dedicaban a la venta o renta de diversos instrumentos, que se importaban de Europa o se construían en México, como ciertos modelos de pianos, arpas o guitarras, así como de música impresa. Caso especial merece la casa Wagner y Levien. En su trabajo particular titulado Casa, centro y emporio del arte musical: la empresa alemana Wagner y Levien en México, 1851-1910 (Moreno, apud Suárez, 2014), Suárez muestra con todo detalle la forma en que dichos individuos construyeron la más grande empresa de venta e importación de instrumentos y música impresa en México; consolidaron redes de comercio con países como Alemania, España, Francia, entre otros. Wagner y Levien edificaron una red de corresponsales en diversos puntos del país. A partir de estos, empresarios particulares, músicos y representantes de instituciones del Estado mexicano se contactaban para la compra, además, de atriles y de métodos de música para el estudio del solfeo y de la práctica del instrumento musical. Existen múltiples pruebas de esto.

Para citar un par de ejemplos he de comentar que, según una nota publicada en La Opinión Libre en 1901 (24 de febrero) en la ciudad de Guanajuato, en la Librería Tovar se vendía música impresa e instrumentos musicales, y en 1902, en la misma ciudad, en El Hijo del Pueblo (30 de noviembre) se anunciaba que Juan de Mata Gurrola había organizado “... dos cuerpos de música, uno para banda y otro para orquesta", habiéndose comprado "el instrumental correspondiente" a la casa Wagner, en la ciudad de México. Algo similar ocurría en la ciudad de Morelia, en el estado de Michoacán. A finales del siglo xix en el portal Matamoros se ubicaba una tienda de venta de música impresa que -se presumía- era importada directamente de Europa. A su vez, el músico Francisco de P. Lemus hacía lo mismo comerciando con impresos originales (Mercado, 2009).

Ahora bien, los instrumentos musicales importados corresponden a la dotación que permitía organizar una orquesta típica con cuerdas y alientos, o una banda de música de viento. En el primer caso, como se observó líneas antes, los instrumentos de cuerda 
arribaron en diversos momentos durante la época colonial, y lo mismo ocurrió con algunos alientos; de hecho, la orquesta ha existido desde el dominio español en América. En el caso de los de aliento, aunque sus antecedentes se remontan a la época prehispánica (Cfr., Martínez, 2018), estudios al respecto coinciden que a mediados del siglo xix aparecieron en México instrumentos con pistones, sistema que revolucionó los alientos-metales, lo que posibilitó la creación de trompetas con dicho sistema, además de trombones, saxhorns, barítono y tuba, y con ello, la dotación fundamental de la banda de música de viento decimonónica.

En el libro que coordinó la investigadora Georgina Flores Mercado en el 2015, cuyo título es elocuente: Bandas de viento en México (Flores, 2015), se evidencia la actuación de dicho grupo musical y con instrumentos de metal modernos, durante la época del imperio de Maximiliano (1863-1867) ${ }^{21}$. Como lo hace notar en el trabajo que Rafael Ruiz Torres incluyó en dicho libro los antecedentes de las músicas de viento están en las bandas de guerra que acompañaban a los regimientos españoles, luego a los ejércitos insurgentes durante la guerra de independencia y, posteriormente, en los cuerpos de policía o en la guardia nacional en la primera mitad el siglo xix. Y aunque no pueden considerarse músicos en toda forma a los corneteros y tamborileros de este tipo de grupo, en las fuentes decimonónicas oficiales solía llamárseles "músicos de banda".

Se dieron casos en que los elementos de banda de guerra formaron las músicas de viento. Esto ocurrió en Morelia, y lo he documentado en el trabajo que incluí en el libro coordinado por Georgina Flores (Mercado, 2015c); la historia es interesante. Un grupo de policías del primer batallón de Morelia que solían hacer música en sus ratos libres, pidieron apoyo al gobernador del estado, Octaviano Fernández, para la compra de instrumentos, música impresa y vestuario adecuado para formar la banda. Pues bien, en 1882 dieron su primera actuación en honor, precisamente, al gobernador, en agradecimiento por el apoyo recibido, y desde entonces se creó formalmente la banda de música del estado de Michoacán (Vid., Mercado, 2015c). Lo mismo sucedió en Guanajuato, cuando en 1855 el gobernador Manuel Doblado creó

21 En un estudio que publiqué en este año (Mercado, 2018b, pp. 71-91), descubro la manera en que las bandas de música con dotación musical moderna actuaban en Guanajuato en la época del imperio de Maximiliano. la música oficial de aquel estado, siendo varios de sus músicos miembros de la banda de guerra del primer batallón de aquella entidad (Guía General del Archivo Histórico, 2001) ${ }^{22}$.

De esta forma, las músicas de viento proliferaron por todo el país -al igual que las orquestas típicas y otros conjuntos de cuerda-, ejecutando las piezas musicales importadas de Europa de compositores clásicos como de aquellas producidas por músicos mexicanos. Al final, de los acordes de estas músicas derivó un nacionalismo musical que, impulsado por las élites intelectuales y políticas, abonó la construcción de un sentido de pertenencia a la nación. De aquel período, provienen piezas que hoy son indispensables en el imaginario social, lo cual, sin embargo, habría de cuestionarse en el período siguiente, cuando un movimiento armado obligó a (re)pensar la nación y sus valores políticos, pero también culturales.

\section{La revuelta musical del siglo XX}

\section{La Revolución Mexicana}

El 20 de noviembre de 1910 se inició en México una Revolución que cambió radicalmente las estructuras de la sociedad mexicana. El origen de la revuelta fue la lucha por el poder político (Bouthoul, 1971) ${ }^{23}$.

Si bien durante el porfiriato se habían generado en el país condiciones de desarrollo importantes, la riqueza alcanzó solo a unos sectores, principalmente las élites y parte de la naciente clase media. Así, las amplias capas campesinas y obreras, donde sobrevivía en la miseria el grueso de la población, en particular los indígenas, no vieron en sus vidas el reflejo de esa modernidad y progreso que tanto se difundía por parte del régimen. A todo esto, en vísperas de la primavera de 1908, en una entrevista con el periodista norteamericano James Creelman, Porfirio Díaz aseveró que había esperado pacientemente a que el país estuviese preparado “... para escoger y cambiar sus gobernantes en cada elección, sin peligro de revoluciones armadas [...]. Creo que, finalmente, ese día

22 Si le interesa al lector, recomiendo leer el artículo titulado Las bandas de música de viento en el Bajío porfiriano (Mercado, 2017), que apareció en la revista Estudios de música sin música, editada por la Universidad Autónoma de la Ciudad de México.

23 Los movimientos militares tienen origen en la ambición por el poder, asegura el profesor Gastón, quien recoge tal idea de los teóricos de la guerra, desde Tzu Sun hasta Homini. De hecho, la historia de toda civilización está determinada por las guerras, que provocan los cambios que determinan las etapas históricas de toda nación, antigua y moderna. 
ha Ilegado" (Creelman, 1963, apud Luján). Y como el oaxaqueño se había reelegido desde 1884 ininterrumpidamente -aunque ostentaba el poder desde $1876-$, y no era precisamente un joven, sus palabras despertaron inquietudes en un sector de hombres en plena madurez política e intelectual. Uno de ellos fue el norteño Francisco I. Madero. En su libro La sucesión presidencial en 1910 (2002), vislumbró un cambio en las estructuras de poder y se apuntó para el relevo político. No obstante, sus palabras, Díaz se reeligió en 1910 y ello derivó en el movimiento armado que terminó con el régimen porfiriano, inaugurando con ello el siglo xx.

La Revolución Mexicana reflejó las aspiraciones de la clase política proveniente de la generación que había nacido en la última década del siglo xIx, así como la situación y legítimas demandas de los grupos marginados (Pozas, 2008) ${ }^{24}$. Un sector político con amplia influencia en el Norte del país protagonizó la lucha por el poder. En tanto, líderes obreros y campesinos encabezaron las demandas de estos, destacando entre todos y por mucho, Emiliano Zapata en el Centro y Francisco Villa en el Norte; estos se convirtieron en verdaderos íconos a quienes la canción popular les ha hecho múltiples homenajes. De esta manera, como se ha identificado plenamente en la historiografía sobre la Revolución, la revuelta significó el ascenso de una nueva clase política en el poder, y el inicio de un proyecto de nación que transformó radicalmente las estructuras políticas, económicas, sociales y culturales.

En este proceso de reestructuración, durante el siglo xx la cultura significó una herramienta eficaz de adoctrinamiento, sobre todo para los sectores populares. Al respecto, el interés de los regímenes revolucionarios fue la difusión por diversos medios, de un nuevo nacionalismo, fundamentado en la idea de que la lucha revolucionaria habría de favorecer el bienestar general $y$, sobre todo, mejorar la vida para los sectores vulnerables, especialmente a los indígenas. Para ello, se usó el arte, como las artes plásticas -principalmente el muralismo-, la literatura ${ }^{25}$ y la música, y se impulsó un proyecto cultural

24 En Juan Pérez Jolote, Pozas (2008) caracteriza no solo la precaria situación de los indígenas de México, sino también de las penalidades a que fueron obligados durante la revuelta, como, por ejemplo, el ser partícipe de determinado bando de manera obligada, sin tener interés alguno en la contienda salvo la imperativa necesidad de sobrevivir.

25 En cuanto al papel de la literatura y su desarrollo en el México del siglo xx, recomiendo la segunda parte del libro $L a$ literatura en los siglos xix y xx, obra coordinada por Antonio Saborit, Ignacio Sánchez y Jorge Ortega (2010). nacional en cuyo centro estaba la educación para abatir el analfabetismo, y desarrollo de la ciencia y del arte. En ello iba la exaltación de los valores en torno a las figuras retóricas de los personajes históricos, en especial los iniciadores de la independencia y los impulsores de la reforma liberal a mediados del siglo xIx, y por supuesto, los preclaros héroes del movimiento revolucionario (Krauze, 2003) ${ }^{26}$. Ello llevó a la configuración de un plan nacional de educación, a cargo de José Vasconcelos, quien fue uno de los personajes fundamentales en la educación y la cultura en el México posrevolucionario.

José Vasconcelos Calderón nació en Oaxaca, el 27 de febrero de 1882. Creció en la ciudad norteña de Piedras Negras, Coahuila, pero a la falta de escuela en dicho lugar, estudió en Texas las primeras letras. Fue un joven que gustó de la lectura. Leyó a Nietzsche, Wagner, Emerson, Carlyle, Tolstoi, entre otros, por lo que forjó un carácter crítico que le permitió valorar las necesidades de su tiempo. Perteneció al selecto grupo de los ateneístas (Vargas, 2010) ${ }^{27}$, y figuró entre los hombres más notables de su tiempo (Blair, $2015)^{28}$. Por su evidente preparación e inteligencia ascendió hasta lograr el puesto de ministro de Educación de México, en 1920, siendo precursor de la creación de la Secretaría de Educación, donde fue su primer secretario en 1921 (Ocampo, 2005) ${ }^{29}$.

Desde esa posición emprendió un ambicioso plan educativo con la premisa de que la educación habría de ser el modo de desarrollo fundamental, pues crearían mexicanos que habrían de identificarse con las necesidades de la patria; de ahí la idea de un nuevo nacionalismo, que debía integrar los elementos

26 Precisamente, el "presidencialismo imperial" -como llamó el historiador mexicano Enrique Krauze Kleinbort a los gobiernos del hegemónico Partido Revolucionario Institucional (PRI)-, legitimó su accionar como consecuencia necesaria a partir del ejemplo contenido en las hazañas de los héroes nacionales, que todo mexicano del siglo xx debió estudiar en las escuelas primarias y de nivel secundario.

27 El Ateneo de la Juventud se fundó en 1909, por un grupo de jóvenes que habrían de destacar en el México posrevolucionario desde la filosofía, las letras y la música. Su influencia en la sociedad mexicana se considera clave para el desarrollo del México del siglo xx. Un trabajo bastante interesante, al respecto, es el de Gabriel Vargas Lozano (2010).

28 Parte de la vida intelectual y, sobre todo, personal de Vasconcelos, está recogida en el libro que sobre Antonieta Rivas Mercado publicó Kathryn Blair. De hecho, la vida de Antonieta es la historia de la cultura en el México posrevolucionario, por lo que bien vale la pena leer el libro de Blair.

29 Sobre Vasconcelos se ha escrito bastante. Su figura es ampliamente reconocida y su obra estudiada allende las fronteras de México. Un ejemplo de ello es el trabajo de Javier Ocampo López (2005), quien examina el proyecto educativo del personaje y su influencia en el panorama educativo latinoamericano. 
culturales heredados del pasado indígena e hispano (Cfr., Matute, 2010). Entre otras cosas, Vasconcelos impulsó la alfabetización con mayor énfasis en sectores vulnerables -en especial, los indígenas-, y dedicó esfuerzos importantes a crear bibliotecas en todo el país. De manera particular, impulsó el muralismo como forma de educación nacional.

En efecto, por medio de las pinturas en muros de sitios emblemáticos de ciudades y pueblos, se transmitió la historia nacional en un interés educativo, solo que aquella historia era la que justamente convenía al régimen; de ahí que se ha llegado a considerar que el muralismo consistió en una manera de generar mitos de origen e identidad en la población mexicana (Vid., Collin, 2003). Como sea, gracias a pintores excelsos, como Diego Rivera (1886-1957), José Clemente Orozco (1883-1949), David Alfaro Siqueiros (1896-1974), sin olvidar una pléyade de pintores regionales que hicieron lo mismo, se vertió en la sociedad mexicana la magnificencia de las culturas indígenas, donde estaría la esencia de lo nacional, lo popular y lo revolucionario, y en oposición, se dispuso la conquista de México como un acto de barbarie. $\mathrm{Y}$ aunque la historia dispuesta en los murales fue evidentemente maniquea y simplista de la historia, surtió el efecto de generar en los mexicanos una conciencia colectiva de lo nacional. Los héroes históricos figuraron, entonces, como los hacedores de la patria y ejemplos a seguir.

A todo esto, la música también fue un motivo de atención. A partir de la década de 1920 y en los años subsecuentes, se proyectó un plan que buscó definir la música perteneciente al país, con lo cual se fortaleció, desde el Estado y sus instituciones culturales, una música de concierto que incluyó motivos musicales y en ocasiones instrumentos de origen prehispánico, por una parte; aunque también se generaron piezas -algunas a manera de popurrí- inspiradas en canciones que provenían de diversas regiones del país y con ello, representativas de ese multiculturalismo musical mexicano. Del siglo xx proviene también la consolidación de los grupos representativos hoy en día de la música mexicana, en su versión contemporánea, específicamente la banda de música de viento, el conjunto norteño y el mariachi. Ello llevó a la bifurcación de la música que se hizo en México en las primeras décadas del siglo $\mathrm{xx}$, en tanto a la música de concierto específicamente Occidental y derivado de ello, las expresiones populares por excelencia, hasta arribar a los albores del siglo xxı con una música popular generada más por intereses comerciales que por un gusto legítimo por el arte, lo cual cambió drásticamente la percepción mayoritaria de lo que se tiene como música mexicana; de esto habré de reflexionar en los apartados siguientes.

\section{Los caminos de la música}

A partir de la década de 1930, el arte musical en México puede mirarse en dos universos. Uno, es el de la música de concierto, que se cultivó con cierta amplitud en diversos lugares del país. Otro, fue el de la música regional, aquella que emergió de los sectores populares, pero que, a diferencia del siglo $\mathrm{xIx}$, adquirió notoriedad nacional por la divulgación de dicha música, a partir de la vitrola, la radio y el cine, que favorecieron el conocimiento sobre la música que se asumió como ranchera, precisamente, por su origen campirano, popular.

La música de concierto se estudió y se hizo en diversas instituciones musicales, siendo el Conservatorio Nacional de Música y la Orquesta Sinfónica Nacional las más emblemáticas (Cfr., Gómez, 2013), aunque no las únicas. En diversos estados del país se abrieron espacios de instrucción musical formal, donde se estudiaba a los clásicos compositores europeos, y se formaban orquestas que reproducían las más significativas obras del repertorio sinfónico ${ }^{30}$. Esto derivó en un culto permanente por la música europea, siguiendo de alguna manera, la herencia decimonónica.

Sin embargo, acorde con el proyecto encabezado por José Vasconcelos, se proyectó una música sinfónica nacionalista. Como acertadamente concluyen Picún y Carredano (2012), se trató de un programa propuesto por las élites culturales, que inició con Manuel M. Ponce (1882-1948) alrededor de 1910, justo en el comienzo de la Revolución Mexicana, y culminó con el proyecto nacionalista posrevolucionario, encabezado por dos destacados compositores: Carlos Chávez (1899-1978) y Silvestre Revueltas (1899-1940). Estos personajes se encargaron de recoger motivos musicales de la herencia prehispánica, por una parte, y, por otra, de la canción popular generada desde finales del virreinato y de las épocas posteriores, que para su tiempo sonaban en variadas regiones del país. Al final, dichos músicos - sin ser

30 Recomiendo consultar, al respecto, el trabajo de Jesús Gutiérrez Guzmán (2017), titulado Orquesta Sinfónica de Michoacán. Orígenes. Se trata de un libro correctamente estructurado, que incluye detalles precisos del devenir histórico -durante el siglo $x x$ - de la orquesta en cuestión, por lo que de su lectura puede comprenderse la necesidad por crear músicas de concierto en México. 
los únicos, por supuesto- compusieron obras que hoy en día son emblemáticas del México musical contemporáneo, que figuran en los programas de concierto sinfónico y que de alguna manera se asumen y aceptan como música mexicana.

Títulos como El fuego nuevo, Los cuatro soles o Sinfonía india, de Carlos Chávez; o La noche de los mayas y Sensemayá, de Silvestre Revueltas, representan ese intento por crear una música nacionalista de calidad musical suprema e inspirada en las culturas prehispánicas. En otros casos, estos y otros compositores crearon obras magníficas de corte sinfónico, donde incorporaron temas musicales inspirados también en la canción popular, que nutría la construcción de ese nacionalismo (Vid., Tello, 2013). De esta manera, durante buena parte del siglo xx se gestó en México una música de concierto que, como afirma con toda razón el musicólogo Aurelio Tello (2013, p. 555) al citar el Huapango, de José Pablo Moncayo, recogió la noción profunda de lo mexicano. En la obra de Moncayo, señala Tello, aparecen las “... maneras de cantar, de tejer ritmos, de superponer métricas; entonaciones, requiebros, sensaciones, evocaciones, sugerencias, timbres, espíritu festivo incluso". Estos elementos que distingue el musicólogo, han permitido que el Huapango sea una pieza ampliamente reconocida en México, tanto en el país como fuera de él. Y aunque no es la única pieza en su tipo, dicha obra representa la creación de la música de concierto nacionalista mexicana, en la más pura inspiración popular.

En otra esfera, una pléyade de compositores mexicanos creó piezas breves o recopilaciones de piezas populares, en significativos popurrís, que ejemplifican una mirada a lo propio, a ese universo de lo que es inherente a la nación en su conjunto. Sería imposible citar, en este caso, todas las piezas emblemáticas de este tipo; pero Estrellita, de Ponce, Janitzio, de Chávez, o los Sones de mariachi, de Blas Galindo (1910-1993), reflejan ese México construido desde los diversos sectores, apropiado y difundido por las élites, pero inspirado en la melancolía y, a la vez, alegría de la canción popular, propia de los sectores pobres de pueblos y ciudades, y de la creciente clase media mexicana.

Las élites mandan: los congresos nacionales de música

Producto también de ese movimiento nacional provocado por la Revolución Mexicana, la música y la actividad musical fueron objeto de una revisión, esto en cuanto a su estudio, práctica y difusión. Por primera vez en México, en 1926 se organizó el Primer Congreso Nacional de Música. En aquella oportunidad participaron varios de los músicos mexicanos más reconocidos, que pertenecían a las élites intelectuales. Estos protagonizaron intensos debates referente a la música considerada mexicana, a las fuentes de inspiración de esa música, y al derrotero del arte en el futuro del país en tanto a su enseñanza y difusión.

En la convocatoria que se publicó al respecto (SEP, 1926), pueden verse con suma claridad las intenciones de la clase artística mexicana atinente a tal reunión. En principio, se dijo que era necesario discutir la orientación de lo que se llamó música nacional. Queda claro el hecho de que se convocaba pensando en que el período histórico anterior, el porfiriato, no había ofrecido la oportunidad de que se construyera una música propia, nacional, que remitiera con exactitud a aquello que se identificase como música mexicana. Como apunta acertadamente la extraordinaria investigadora mexicana María Esther Aguirre Lora (2016), desde 1913 Manuel M. Ponce insistía en una decadencia del arte musical en el país, ocasionada por haberse centrado el desarrollo musical en el "cosmopolitismo europeo". Por ello, Ponce señalaba la necesidad de una revisión de lo hecho hasta ese momento en el ámbito del desarrollo musical.

Precisamente, una de las razones para la convocatoria al congreso de 1926 - una segunda edición se llevaría a cabo en 1928-, era que debía crearse una cultura musical; pues, para entonces, lo que se venía haciendo era solo un reflejo de la música europea. Evidentemente, existía en México una cultura musical, por herencia de las épocas históricas anteriores, pero los músicos que asistieron al congreso pretendían definirse ellos mismos y definir la música por ellos generada, en función de lo mexicano o lo que concebían como lo mexicano. Es interesante, en este caso, el que se haya discutido ampliamente la necesidad de profundizar en el folclor musical de las regiones del país. En dicho folclor estaría la identidad de la música mexicana.

De esta manera, con temas como El folk-lore como fenómeno histórico, ponencia presentada por Daniel Castañeda y Gerónimo Baqueiro en la reunión de 1928, o La música mexicana, de la autoría de Luis Sandi, sin olvidar el Estudio de nuestra prehistoria musical como factor importantísimo en la especulación folklórica de México, que corrió a cargo de Carlos C. Romero, los músicos mexicanos intentaron en las 
dos reuniones (re)encauzar la música que se hacía en el territorio; incluso, se habló de incorporar en el Conservatorio Nacional una cátedra que Ilevara el nombre de Historia de la música mexicana ${ }^{31}$ (Miranda, 2013).

En total, se presentaron 48 ponencias en seis temáticas: acústica musical; organografía; teoría y composición musicales; pedagogía musical; folclor y temas libres. Y aunque se trabajó en la idea de dignificar el arte músico-nacional y la revisión del folclor -la canción popular como fuente de la música mexicana-, hubo una contradicción mayúscula: no se permitió en el congreso la participación de músicos populares. En efecto, los grupos de músicos que encabezaron los trabajos y las discusiones, liderados por Carlos del Castillo (1882-1959), Julián Carrillo (18751965) y Alba Herrera y Ogazón (1885-1931), determinaron que debía darse cabida en el congreso, solo a los mejores y serios músicos mexicanos, excluyendo a los músicos populares por ser ajenos a los círculos ilustrados (Cfr., Aguirre, 2016).

Por consiguiente, la música en México, en ese momento de coyuntura, se debatió desde las élites, que favorecieron la enseñanza de la música en conservatorios y escuelas especializadas, no solo en la capital del país, sino también en las distintas regiones del territorio. Además, aprovechando su influencia intelectual y política, se dieron a la tarea de estimular la composición sobre temas nacionalistas, aunque como ya se ha señalado, inspirados en la canción popular, aquella es producto de la creatividad de los músicos que habían sido desdeñados en los congresos nacionales de música. Como sea, y se verá en seguida, la música popular detonó sin la necesidad de las élites, transformando el México musical también desde la década de 1930.

\section{El otro México musical}

Hoy en día, en el país y desde el exterior, son reconocidos tres grupos musicales que sintetizan y representan la música popular mexicana: el mariachi, el conjunto norteño y la banda de música de viento. Como se señaló en su momento, estos grupos tienen sus antecedentes en el siglo xIx. Sin embargo, su consolidación instrumental, repertorio musical y de imagen, más aún su difusión nacional

31 La propuesta corrió a cargo de Jesús C. Romero y fue debatida porque, para algunos, la historia de la música en México no tenía ni ochenta años. e internacional, ocurrió en dos momentos durante el siglo xx. Uno, fue en la década de 1930 cuando se dieron las primeras grabaciones y se popularizaron piezas que hoy son ícono del nacionalismo mexicano, aun cuando este se haya dado por un proceso de comercialización. Como quiera, fue en las postrimerías del México posmoderno que estos grupos se consolidaron como referentes de la música popular mexicana. Otro momento clave, ocurrió en la década de 1990, cuando las empresas televisivas convirtieron las músicas populares en un producto comercial homogéneo. Esto cambió radicalmente la visión de lo que es la música mexicana.

Las músicas de viento -decía antes- se originaron en el siglo xix. Nacieron con un carácter de bandas militares, por acompañar los cuerpos de milicia en sus inicios como grupo musical. Para el período posrevolucionario, aunque no desaparecieron las bandas oficiales, emergieron con mayor frecuencia músicas particulares, que recogieron en sus ejecuciones las piezas más representativas de la canción popular. Una de las bandas de mayor renombre en México es la banda El Recodo. Se fundó en 1938 y tuvo como inspiración, según testimonio de su fundador, Cruz Lizárraga, las Big Band norteamericanas (Banda El Recodo, 2018); de estas adquirieron su especial sonoridad en cuanto a presencia y fuerza interpretativa. El Recodo creó un estilo que permeó en las músicas mexicanas, y aunque no fue la única en el proceso, significó el ejemplo a seguir. Sus grabaciones recogieron piezas de dominio popular y regional, y composiciones originales que se crearon para música de viento, y al paso de los años, la música de ese tipo sería uno de los grupos representativos de la música popular mexicana.

En cuanto al conjunto norteño, el consenso historiográfico indica su origen en el Norte del país. Al parecer, en algún momento en la década de 1860, un grupo de inmigrantes alemanes llevó el acordeón a la frontera con los Estados Unidos, dándose la fusión a principios del siglo xx, con el bajo sexto. Como dato curioso, la música norteña como tal, es una invención de la industria cultural. En efecto, gracias a las grabaciones que se hicieron en los Estados Unidos, que se difundieron con efectividad por medio de la radio, del fonógrafo y del cine, en todo el territorio nacional, catapultó dichas agrupaciones, haciéndolas parte fundamental de la música mexicana (Cfr., Díaz, 2015; Montoya, 2014). 
El mariachi también se consolidó en su formación instrumental moderna, en la década de 1930. Según se ha descubierto, fue en las instalaciones de la emisora XEW, en la ciudad de México, que el empresario Emilio Azcárraga Milmo, al escuchar a unos músicos que habían emigrado a la capital procedentes de Cocula, Jalisco, les impuso las trompetas y el traje de charro (Chamorro, 2006), y se les incluyó en programas populares y en películas que reflejaban la vida en el campo mexicano. Se popularizó, entonces, el mariachi, que hoy es considerado patrimonio de la humanidad, no importa que en su historia particular sea, de hecho, una tradición inventada (Ochoa, 2015) (2. $^{32}$.

La música en México dio un vuelco, como se ve, en la década de 1930. La consolidación de las músicas de viento en su faceta popular, la conformación moderna del mariachi y del conjunto norteño modificaron la noción de la música mexicana. Sobre todo, debe tomarse el papel de los medios, en especial la radio y el cine, en la conformación de lo mexicano. Ello implica reconocer que parte de lo que hoy se considera propio, nacional, tuvo mucho de su origen en el interés comercial; aunque debe también reconocerse que sin el apoyo de la empresa es probable que no se hubiese dado el desarrollo de compositores populares, como José Alfredo Jiménez, quien encarna el mejor ejemplo de la creatividad natural, sin olvidar en todo esto, el aporte a la canción mexicana del inolvidable Rubén Fuentes (1926), a quien se le debe no solo parte de las piezas más representativas de la música ranchera mexicana, sino también varios de los arreglos más significativos del cancionero mexicano contemporáneo.

La trasformación radical de las músicas populares mexicanas ocurrió en la década de 1990. Su incorporación al medio del espectáculo en función de los intereses de un mercado en ascenso catapultó las bandas de viento y el conjunto norteño; el mariachi se quedó a la zaga de esa popularización comercial. Televisa, la empresa mexicana más importante en ese momento -luego entraría al negocio TvAzteca-, incluyó artistas y músicas populares en sus programas Siempre en Domingo, con Raúl Velasco, o en los dirigidos por Verónica Castro, como Mala noche...

32 La difusión del mariachi corrió a cargo también de los propios músicos, sobre todo en los Estados Unidos, según ha estudiado el historiador Álvaro Ochoa Serrano (2015) en su libro La música va a otra parte. Mariache México-USA. Se trata de un libro de lectura obligada para comprender las músicas populares mexicanas y su difusión por los mismos intérpretes.
¡No! (1988), Aquí está (1989), La movida (1991), e Y Vero América iVa! (1992).

Lo anterior hizo que la televisión mexicana fuese el móvil para que se conocieran artistas de extracción popular, que determinaron la música mexicana de finales del siglo xx. Esto modificó sustancialmente las preferencias musicales de los mexicanos, de tal suerte que, de acuerdo con la Encuesta Nacional de Hábitos, Prácticas y Consumo Cultural (Conaculta [Consejo Nacional para la Cultura y las Artes], 2010), la mayoría de los mexicanos consume la música generada en función de un mercado, es decir, la música popular comercial y, en menor escala, la música regional tradicional. Al respecto del consumo de la música clásica, el resultado es pobre. Las salas de concierto mexicanas solo captan el tres por ciento de las preferencias del público mexicano, la ópera el dos por ciento, en tanto que la música de banda y norteña sobrepasa el sesenta por ciento de las preferencias.

Es interesante la forma en que la música popular mexicana se posicionó en el gusto masivo de la población mexicana. En los años noventa se popularizó en México la organización de bailes multitudinarios. En abril de 1992 se organizó uno de ellos en la ciudad de Monterrey, Nuevo León, rompiendo récord de asistencia. Al respecto, los Tigres del Norte $^{33}$ y el grupo Bronco ${ }^{34}$ (Bronco, 2018) contabilizaron una asistencia de 125000 personas. Tal poder de convocatoria significó en aquellos momentos una mina de oro para las empresas televisivas, que crearon en su organización interna una división especial para atender el negocio del espectáculo, lo que incluía marca discográfica y canales de distribución, la Revista "Grupera" -tal nombre se dio a los grupos populares: bandas, norteños y sus derivados- y toda una estructura de comercialización que dio valor agregado a la música popular mexicana, que se distingue del resto por tener como objetivo principal el cumplir metas de mercado.

Hoy en día, entonces, la música más popular en México en todos los sectores sociales es aquella que se produce y difunde por medio de la estructura de la empresa musical, aunque la historia está por modificarse con la incorporación en la vida actual, de

33 Los Tigres del Norte de formaron en 1968. Datos sobre su historia pueden consultarse en la página oficial de dicha agrupación (Los Tigres del Norte, 2018).

34 Bronco se fundó en Apodaca, en el Estado mexicano de Nuevo León, en 1979. Es uno de los grupos populares con mayor audiencia en la historia de la música en México. 
las redes sociales, que se está convirtiendo en una ventana de difusión de creadores de música popular, ejemplo especial son los Tres Tristes Tigres. Se trata de un trío que se ha dado a conocer por medio del Internet, y cuya propuesta artística es hacer parodia de las piezas más representativas del género popular comercial (Los Tres Tristes Tigres, 2018).

En fin, las culturas son dinámicas, y la música se ajusta a las necesidades de cada generación, por lo que se verá en el futuro cercano nuevas maneras de concebir el arte, todas legítimas si se considera que, aun con una imposición comercial, es la sociedad la que decide el consumo musical.

\section{A manera de conclusión}

El estudio ha dejado en claro el que en cada período de la historia de México el arte ha estado presente, e incluso, ha servido como una herramienta para forjar el sentido de pertenencia. El interés principal del presente trabajo tiene como propósito mostrar las épocas históricas que, a mi juicio y en mi experiencia como historiador de la música, los músicos y las músicas por ellos formadas, han sido fundamentales en el arribo de componentes de la cultura europea, que, a partir de un proceso, a veces doloroso, de aculturación, favorecieron el surgimiento de la identidad musical que hoy pertenece y da unidad plena, al México musical.

Al inicio me cuestionaba sobre cómo distinguir los elementos propios de la tradición musical mexicana, y apuntaba que tal cosa podría dilucidarse a partir de una revisión, precisamente, de la historia de la música en México. Así ha sido. Durante el desarrollo del presente trabajo ha podido distinguirse en cada etapa histórica abordada y en cada momento preciso de la misma, el arribo de la música, los instrumentos $y$, en general, las formas musicales de Occidente, lo cual favoreció el mosaico musical cultural contemporáneo nacional. Esto se explica si se entiende que los elementos culturales impuestos por una cultura determinada a otra, luego de ser asimilados por esta, los transforma para sí y les da un nuevo significado (Colombres, 2009). Es por esto por lo que el violín que se ejecuta en las músicas populares mexicanas no suena como el de concierto, y lo mismo ocurre con cualquier otro instrumento y ejecución musical: la transformación cultural hizo su parte.
Para concluir, he de comentar que en un México actual donde la música comercial domina, es perenne la música popular tradicional, que se desarrolla en las regiones del país y con mayor presencia en zonas indígenas. La característica principal de estas expresiones y que la contrapone a la comercial, no se genera en función de un mercado, sino que se crea en torno a una necesidad cultural legítima, en respuesta a los festejos regionales, religiosos y sociales. Esto favorece la conservación de las músicas representativas de cada región de México, y complementa de forma extraordinaria el mosaico musical mexicano.

\section{Referencias}

Adorno, T. W. (2000). Sobre la música. España: Paidós.

Aguirre, M. E. (2016). Revuelo entre los músicos académicos: los primeros congresos nacionales de música (1926-1928). Revista Iberoamericana de Educación Superior, VII(20), 79-93.

Amós, J. (2000). iEpa! Toro prieto. Los toritos de petate, una tradición de origen africano traída a Valladolid por los esclavos de lengua Bantú en el siglo XVII. México: Instituto Michoacano de Cultura.

Amós, J. (2018). ¡Ay! Tengo mi clarín sonoro... Las trompetas de metal y los militares pardos en el Michoacán novohispano. En Díaz Santana, L. (coord.), La investigación musical en las regiones de México (pp. 13-37). México: Universidad Autónoma de Zacatecas, Texere Editores S.A. de C.V.

Banda El Recodo. (2018). Biografía. Recuperado el 2/08/2018, de https://www.bandaelrecodo. com.mx/biografia/.

Blair, K. (2015). A la sombra del ángel. México: Penguin Random House grupo editorial.

Bolaños, R. (2010). Orígenes de la educación pública en México. En Solana, F., Cardiel Reyes, R. y Bolaños Martínez, R. Historia de la educación pública en México (pp. 12-40). México: Fondo de Cultura Económica.

Bonfil, G. (1989). México profundo. Una civilización negada. México: Fondo Nacional para la Cultura $\mathrm{y}$ las Artes.

Bouthoul, G. (1971). La guerra. Colección ¿Qué sé? No. 44. España: Oikos-Tau, S. A.

Brennan, J. A. y Sarquiz, Ó. (2009). La música en México. Letras libres (124), s./p. Disponible en http://www.letraslibres.com/mexico/la-musica-en-mexico.
21

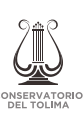


Bronco (2018). Biografía. Recuperado el 2/08/2018, de https://www.broncoesbronco.com.

Chamorro, A. (2006). Mariachi antiguo, jarabe y son. Símbolos compartidos y tradición musical en las identidades jaliscienses (pp. 54-56). México: Secretaría de Cultura, Gobierno de Jalisco.

Civallero, E. (2015). Caparazones de tortuga en la música tradicional latinoamericana. Madrid: Edgardo Civallero.

Collin, L. (2003). Mito e historia en el muralismo mexicano. En Scripta Ethnologica, (25), 25-47.

Colombres, A. (2009). Nuevo manual del promotor cultural (vol. 1). México: Consejo Nacional para la Cultura y las Artes.

Conaculta - Encuesta Nacional de Hábitos, Prácticas y Consumo Culturales. (2010). Consejo Nacional para la Cultura y las Artes. Recuperado el 2/08/2018, de https://www.cultura.gob.mx/recursos/banners/encuesta_nacional.pdf.

Constitución Política de los Estados Unidos Mexicanos. (Última reforma publicada del 2017). México: Cámara de Diputados del H. Congreso de la Unión. Recuperado el 16/06/2018, de http://www.diputados.gob.mx/LeyesBiblio/ pdf/1_150917.pdf.

Creelman, J. (1963). El presidente Díaz. Héroe de las Américas. En Luján, J. M. (prólogo). Entrevista Díaz-Creelman. Serie documental No. 2. México: Universidad Nacional Autónoma de México.

Dájer, J. (1995). Los artefactos sonoros precolombinos. México: Fondo Nacional para la Cultura y las Artes.

Díaz, L. (2015). Historia de la música norteña mexicana. México: Plaza y Valdés Editores.

División territorial de los Estados Unidos Mexicanos, correspondientes al censo de 1910. (1917). México: Departamento de Talleres Gráficos de la Secretaría de Fomento.

El Hijo del Pueblo. (1902). Periódico Semanario. Guanajuato: Imprenta de la Escuela Industrial Militar.

Flores, G. (coord.). (2015). Bandas de viento en México. México: Instituto Nacional de Antropología e Historia.

Gómez, A. (2013). Instituciones musicales. La conformación de una cultura musical en el México del siglo xx. En Miranda, R. y Tello, A. (coords.). La música en los siglos xix y xx (pp. 371-415). Colección: El patrimonio histórico y cultural de México, tomo IV. México: Consejo Nacional para la Cultura y las Artes.
González, M. (1974). El porfiriato. La vida social. En Cosio Villegas, D., Historia moderna y contemporánea de México ( $2^{\mathrm{a}}$ ed.) (vol. 1). México: Hermes.

Guía General del Archivo Histórico. (2001). Guanajuato: Archivo General del Gobierno del Estado de Guanajuato. 82

Gutiérrez, J. (2017). Orquesta Sinfónica de Michoacán. Orígenes. México: Gobierno del Estado de Michoacán, Secretaría de Cultura de Michoacán, Secretaría de Cultura Federal.

Hammeken, L. de P. (2018). La República de la música. Ópera, política y sociedad en el México del siglo xix. México: Bonilla Artigas Editores.

Krauze, E. (2003). La presidencia imperial. Ascenso y caída del sistema político mexicano (1940-1996). México: Fábula Tusquets.

La Opinión Libre. (1901). Semanario Independiente. Guanajuato: imprenta a cargo de Manuel Palencia.

Leal, J. F. (2009). Anales del cine en México, 1895-1911. 1900, tercera parte, el circo y el cinematógrafo. México: Juan Pablos Editor, S. A.

León, M. (1974). Historia documental de México. México: Universidad Nacional Autónoma de México.

León, M. (2006). La visión de los vencidos. Relaciones indígenas de la conquista (28 ed.). México: Universidad Nacional Autónoma de México.

Los Tigres del Norte. (2018). Biografía. Recuperado el 2/08/2018, de http://lostigresdelnorte.com/ main/.

Los Tres Tristes Tigres. (2018). Sitio oficial. Recuperado el 3/08/2018, de https://www.lostrestristestigres.com.

Madero, F. (2002). La sucesión presidencial en 1910. México: Época, S. A.

Marroquín, G. M. (2004). Aspectos generales de la música prehispánica percibidos a través de sus imágenes. Tesis para obtener el grado de maestría en Artes, especialidad en Educación por el Arte. México: Facultad de Artes, Universidad Autónoma de Nuevo León.

Martínez, J. A. (2000). iEpa! Toro prieto. Los toritos de petate. Una tradición de origen africano traída a Valladolid por los esclavos de lengua Bantú en el siglo xvII. México: Instituto Michoacano de Cultura. 
Martínez, J. A. (2018). ¡Ay! Tengo mi clarín sonoro... Las trompetas de metal y los militares pardos en el Michoacán novohispano. En Díaz Santana Garza, L. (coord.), La investigación musical en las regiones de México (pp. 13-37). México: Universidad Autónoma de Zacatecas, Texere Editores, S. A. de CV.

Matute, Á. (2010). La política educativa de José Vasconcelos. En Solana, F., Cardiel Reyes, R. y Bolaños Martínez, R. (coords.). Historia de la educación pública en México (1876-1976) (pp. 166-182). México: Fondo de Cultura Económica.

Mazín, O. (2006). La música en las catedrales de la Nueva España. La capilla de Valladolid de Michoacán (siglos xvI-XvIII). En Enríquez, L. y Covarruvias, M. (eds.). Música, catedral y sociedad (pp. 205-2018). México: Universidad Nacional Autónoma de México.

Mendoza, V. (1984). Panorama de la música tradicional de México. México: Universidad Nacional Autónoma de México.

Mercado, A. (2009). Los músicos morelianos y sus espacios de actuación. México: Gobierno del Estado de Michoacán.

Mercado, A. (2015a). Lo europeo frente a lo mexicano en la música: el caso de Euterpe, revista de música, literatura y variedades, 1892-1894. En Trans, Revista Transcultural de Música, (19), 16 pp.

Mercado, A. (s./f.). Las bandas de viento en el Bajío porfiriano. Disponible en https://www.uacm.edu. $\mathrm{mx} /$ Portals/28/Numeros/2/1_Alejandro-2.pdf.

Mercado, A. (2015b). La educación musical en Morelia, 1869-1911. México: Universidad Michoacana de San Nicolás de Hidalgo.

Mercado, A. (2015c). Las bandas de música en Morelia. Un acercamiento a la música de las mayorías, 1882-1911. En Flores Mercado, G. (coord.). Bandas de viento en México (pp. 71-108). México: Instituto Nacional de Antropología e Historia.

Mercado, A. (2018a). Música y fiesta en Guanajuato. Notas sobre la vida cotidiana en dos ciudades del Bajío porfiriano. México: Forum Cultural Guanajuato.

Mercado, A. (2018b). iQue viva Maximiliano! Música y fiesta en Guanajuato durante el México imperial. En Meneses Sánchez, C. Cultura y patrimonio. Ensayos. México: Universidad de Guanajuato, Editorial Montea.
Miranda, R. y Tello, A. (coords.). (2013). La música en los siglos xIx y xx. Colección: El patrimonio histórico y cultural de México (tomo IV). México: Consejo Nacional para la Cultura y las Artes.

Miranda, R. (2013). Identidad y cultura musical en el siglo xix. En Miranda, R. y Tello, A. (coords.). La música en los siglos xix y xx (pp. 15-80). Colección: El patrimonio histórico y cultural de México (tomo IV). México: Consejo Nacional para la Cultura y las Artes.

Montoya, L. O. (2014). El síndrome de la nostalgia. México: Universidad de Guanajuato.

Moreno, O. (2014). Casa, centro y emporio del arte musical: la empresa alemana Wagner y Levien en México, 1851-1910. En Suárez de la Torre, L., Los papeles para Euterpe. La música en la ciudad de México desde la historia cultural. Siglo XIx. México: Instituto Mora.

Moreno, Y. (1979). Panorama de la música popular mexicana. México: Alianza Editorial Mexicana, Fondo Nacional para la Cultura y las Artes.

Ocampo, J. (2005). José Vasconcelos y la educación mexicana. Rhela, 7, 137-157.

Ochoa, Á. (2015). La música va a otra parte. Mariache México-USA. México: El Colegio de Michoacán, El Colegio de Jalisco.

Ortega, A. (2010). Gabino Barreda, el positivismo y la filosofía de la historia mexicana. Revista de Hispanismo Filosófico, (15), 117-127.

Picún, O. y Carredano, C. (2012). El nacionalismo musical mexicano: una lectura desde los sonidos y los silencios. En Ramírez, F., Noelle, L. y Arciniega, H. (coords.). El arte en tiempos de cambio 1810-1910-2010. México: Instituto de Investigaciones Estéticas, Universidad Nacional Autónoma de México.

Pineda, A. y del Palacio, C. (coords.). (2003). La prensa decimonónica en México. México: Universidad Michoacana, CONACyT, Universidad de Guadalajara.

Pozas, R. (2008). Juan Pérez Jolote: biografía de un Tzotzil (30 reimpr.). México: Fondo de Cultura Económica.

Ramos, S. (1968). El perfil del hombre y la cultura en México. México: Espasa-Calpe Mexicana, S. A.

Ramos, M. (2010). Los artistas de la feria y de la calle: espectáculos marginales en la Nueva España (1519-1822). México: Instituto Nacional de BeIlas Artes y Literatura.
23

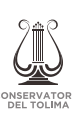


Rodríguez-Erdmann, F. J. (2007). Maestros de la capilla vallisoletanos: estudio sobre la capilla de la catedral de Valladolid-Morelia. México: El autor.

Romero, J. C. (1934). José Mariano Elízaga. México: Ediciones del Palacio de Bellas Artes.

Ruiz, R. A. (2015). Las bandas militares de música en México y su historia. En Flores Mercado, G. (coord.). Bandas de viento en México (pp. 2144). México: Instituto Nacional de Antropología e Historia.

Saborit, A., Sánchez, I. M. y Ortega, J. (coords.). (2010). La literatura en los siglos XIX y Xx. Colección: El patrimonio histórico y cultural de México (1810-1910) (tomo V). México: Consejo Nacional para la Cultura y las Artes.

Secretaría de Educación Pública (SEP). (1926). Convocatoria, bases y reglamento del Primer Congreso Nacional de Música. México: Talleres Gráficos de la Nación.

Schöndube, O. (1986). Instrumentos musicales del Occidente de México: las tumbas de tiro y otras evidencias. Relaciones, VIII(28), 85-110.
Suárez, L. (2014). Los papeles para Euterpe. La música en la ciudad de México desde la historia cultural. Siglo xix. México: Instituto Mora.

Tapia, S. (1991). Música y músicos en México. México: Panorama Editorial. 23

Tello, A. (2013). Rasgos nacionales en la música mexicana de concierto del siglo xx. En Miranda, R. y Tello, A. (coords.). La música en los siglos xixy $x x$ (pp. 494-572). Colección: El patrimonio histórico y cultural de México (tomo IV). México: Consejo Nacional para la Cultura y las Artes.

Torres, R. H. (2016). Música y catedral. Nuevos enfoques, viejas temáticas. México: Universidad Autónoma de la Ciudad de México.

Unesco. (2011). El mariachi, música de cuerda, canto y trompeta. Recuperado el 15/07/2018, de https://ich.unesco.org/es/RL/el-mariachi-musica-de-cuerdas-canto-y-trompeta-00575.

Vargas, G. (2010). El Ateneo de la Juventud y la revolución mexicana. Literatura Mexicana, XXI(2), 27-38. 
Editorial

\section{Música y cultura}

La Música en México: Reflexiones sobre su historia particular The Music In México: Notes his particular history Alejandro Mercado Villalobos

25 Ecos lejanos de una disputa conceptual: El nacionalismo musical en Nariño Echoes far from a conceptual dispute: Musical Nationalism In Nariño José Menandro Bastidas España

45 Dos Órganos Históricos en Ibagué: Aportes para la contextualización de la tradición organística en Colombia Two historical musical organs in Ibagué: Contributions for the contextualization of the organist tradition in Colombia Nicolás Forero Molano, Mayerlín Alejandra Gómez Guzmán, Julián David Perdomo Rodríguez

63 Evidencias de la recepción del bambuco colombiano en Yucatán. (1908-1920)

Evidences of the colombian bambuco reception in Yucatán (1908-1920)

Claudio Ramírez Uribe

\section{Música y pensamiento}

81

La composición de los Tres Ballets Criollos de Guillermo Uribe Holguín como producto de exportación colombiano para un escenario panamericano

The creation of the Tres Ballets Criollos by Guillermo Uribe Holguín as a Colombian national export product for a

Pan-American scenario

Camilo Vaughan Jurado

93

Métodos y textos adoptados para la enseñanza de música de 1880- 1920 Métodos utilizados en educación informal y métodos para enseñanza de canto en las escuelas

Texts and methods used for music teaching from 1880 to 1920: Methods used in informal education and methods for singing teaching at schools Martha Lucía Barriga

\section{Música, Educación Musical y Género}

104

Identidad, yuxtaposición y resistencia:

tres categorías para entender la música

latinoamericana para piano a comienzos del siglo XX

Identity, juxtaposition and resistance: three categories to understand the Latin-American piano music of the beginning of 20th century

Mónica Tobo Medivelso

Música, educación musical y género.

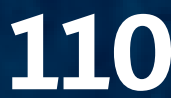
Un estudio sobre la participación de la mujer de la zona andina nariñense en la interpretación (instrumental y vocal), la educación musical y la composición Music, musical education and gender A study on the participation of women in the Andean area of Nariño in the interpretation (instrumental and vocal), music education and composition

Lyda Tobo Mendivelso, José Menandro Bastidas España

\section{Música en clave}

Creación orquestal de la obra para piano Fantasía Romántica de Maruja Hinestrosa

Orchestral creation about Maruja

Hinestrosa's Fantasía Romántica concert for piano and orchestra

Julián Augusto Castro Gaviria,

Anthony Sebastián Chunganá, Andrés Felipe Gómez

\section{Separata}

Fantasía Romántica Sobre Aires Colombianos Concierto para piano y orquesta de Maruja Hinestrosa

Orquestación: Julián Augusto Castro Gaviria

Convocatoria Revista No. 9

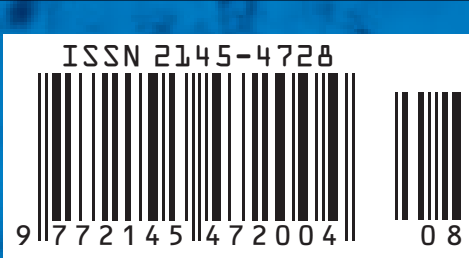

